\title{
Chinese Space Law: Problems and Areas of Reforming
}

\author{
Olga Yeshchuk
}

\author{
Doctor of Law, Associate Professor, Kherson State University (Kherson, Ukraine). \\ E-mail: eschyk-o@ukr.net \\ https//orcid.org/0000-0002-7458-1595
}

\begin{abstract}
Anna Vasina
Graduate student at the Public Law Research Institute, Hangzhou Pendant Technology Co. Ltd (Zhejiang, China).

E-mail: annavasina1992@gmail.com https//orcid.org/0000-0003-2280-8556
\end{abstract}

\begin{abstract}
In the article, we have determined that China is a leading, but the only space state that does not have a special space law. These activities are governed by the international norms-principles, international treaties and by-laws of the government. We consider that such a procedure for regulating legal relations in the space industry is illogical. We have revealed the contours of the future space law of China in the article. We've noted that the signing of a Memorandum of Understanding on Space Cooperation with Luxembourg will have a positive impact on the exploration and utilization of mineral resources from the Moon and asteroids by Chinese space companies. At the same time, we have concluded that without the adoption of a special space law, foreign investments in the Chinese space industry and space tourism will be constrained.
\end{abstract}

Keywords: White paper, space, law, normative legal acts, legislation.

Received: December 21, 2018; accepted: February 27, 2019

Advanced Space Law, Volume 3, 2019: 140-150.

https://doi.org/10.29202/asl/2019/3/12

\section{Introduction}

The problems of Chinese national space law is the central one, because China is a leading space power, but does not have its own national space law. This contradiction constrains foreign investments in the Chinese space industry and calls into question the transparent fulfilment by Chinese space companies of their international obligations. There is very little scientific literature on this issue, and the available one covers this problem only in the certain aspects.

(C) Yeshchuk, Olga, 2019

(C) Vasina, Anna, 2019 
China, as a leading space power, has made significant progress in the exploration and use of outer space, thanks to the strict centralization of scientific space research conducted mainly by the military. At a certain stage in the development of space programs, this was beneficial. However, the military became the main obstacle to the adoption of Chinese civil law to regulate space activities, as the theory of law objectively requires. Indeed, the economic basis in the field of research and use of outer space is far ahead of the legal superstructure in this area. In addition, a significant factor in the adoption of the law under consideration is the implementation of the rule of law with Chinese characteristics in all spheres of public life. Its acceptance has objectively matured.

The content of the article is structured as follows. First, we analyze the White Papers of China's space activities. Then our attention will be focused on the successes and plans of China in the exploration and use of outer space. Particular attention will be paid to the current state of national space legislation. At the end of the article, we will reveal the author's understanding of the basic principles of the future Chinese special space law.

\section{White Papers on space activities as a basis for China's space law formation}

In China, exploration and use of outer space are carried out in accordance with the socalled Outer Space White Papers, which are adopted regularly (every five years) by the State Council of China in 2000, 2006, 2011, and 2016 [White Paper, 2017].

The successes and challenges of China in space exploration and use of outer space are analysed, and plans for the next five years are outlined in these books. In practice, the provisions of these books are the principles on the basis of which all directions in the space industry are developing, including the principles of national civil space law. The ambitious task of building an advanced and developed cosmic power runs through them as the central theme.

It should be noted that China's Space White Paper is not just a set of texts with generalizations and space planning activities. This is the scientific and practical matter of building new China as a leading space state, which considers space as an important tool for realizing the dream of the Chinese nation, as an independent world leader in science and technology. The latest book (2016) emphasizes that China lost its dependence on science and space technology in Russia [Goh, 2017].

It should be understood that the legal and organizational factors of space activities are subordinated to the overall national strategy development based on the principles of the rule of law with the Chinese specifics. The content of the rule of law in China is a closely related triad: (1) the state of law; (2) the government of the rule of law; and (3) the society of the rule of law [Jinping, 2017].

It is difficult for the European reader to understand the essence of the rule of law with Chinese specifics. However, let's try to describe it briefly. The first thing to note is that the theoretical thinking and practice of the Chinese rule of law is based on the theoretical postulates of Marxism, not dogmatic, but taking into account the modern time and the Chinese traditions. When the process of government is carried out in accordance with the law and on the basis of Marxist theory of law and practice of a socialist legal state with Chinese characteristics. After all, according to Chinese scholars, the rule of law in any country not only reflects the universality and community, but also the peculiarity and individual development of each state. Such features include the specific legal culture of Chinese citizens and the understanding 
that the development of the rule of law cannot go beyond the stages of economic and social development. At the same time, the Chinese principle of the rule of law has common features with its Western understanding, namely that people are the basic essence of law. In the view of Chinese scholars, in a democratic system, people do not exist for the law, but the law exists for the people. The law is the embodiment of the will of the people [Feng, 2018].

The principle of rule of law under review proves that: firstly, it is the basis for the formation of the national civil space law; secondly, it clearly proves that such a law should be adopted by the National Assembly of China. After all, without it, it will be difficult to adhere to the declared principle of the rule of law, with Chinese signs of values.

The White paper on space activities for 2016 also contains special principles for the exploration and use of outer space, namely the principles of innovative development, coordinated, peaceful, and open development.

Innovative development means that new discoveries and new technologies should become the basis for the development of the space industry. The implementation of major space research projects will stimulate space research and technology, support institutional reforms that will contribute to the rapid development of the space industry [White Paper, 2017]. Based on this principle, we justify the need to create a full-fledged civil national space law. After all, its absence hinders the innovative development of the space industry. It is in this area that a strong and prudent institutional reform is needed.

Therefore, the Space White Paper for 2016 is a kind of Chinese constitution for the next five years, based on the general principle of the rule of law with Chinese features, on the one hand, with the starting points for national civil space law on the other. The provisions of this book provide an opportunity for national and international companies to be confident that the use of outer space from China will be the first to make a profit, and Chinese citizens will become more affluent through the effective use of outer space opportunities.

\section{The impact of the latest research in the space industry on the development of China's national space law}

Chinese scientists pioneered the creation of archaic rockets, which had been launched in the early tenth century. Although the first rocket in the modern sense was launched only in 1970, and the first citizen of China was sent into space only in 2003. However, in the last decade, there has been a dynamic and successful development of both the science and practice of the Chinese space [Campbell, 2019].

Among the directions of successful space activity of the last decade are the following: first, the launch of space carriers. In recent years, Chinese missiles have taken the first place in the world in launching and putting into orbit high-reliability spacecraft.

Successful launches of space carriers, including private ones, require the transfer of these programs from the military, which now launch missiles, into civilian structures. And the Chinese civilian missile launch industry should be governed by open law (space law), not by secret military orders.

Second, various artificial Chinese satellites are successfully operating in the Earth's orbit, which by their purpose are divided into satellites: surveillance, communication and broadcasting, navigation and positioning, and new experimental satellites, which are the leading ways of testing new technologies. 
Third, the manned space program. In 1992, China defined a phased strategy for the development of manned space from scientific experiments in orbit with unmanned spacecraft and simulated manned flights to the first successful flight (October 15, 2003)1.

Fourth, deep space exploration. The beginning of this study was in 2012, when the Chang'e-2 space probe successfully monitored asteroid 4179 (Toutatis). The world's largest radio telescope has been already operating on the Chinese territory. China plans to carry out a mission to Mars, send probes to asteroids, Jupiter and even Uranium. In December 2013, Chang'e-3 made its first soft landing on the surface of the Moon. In the future, China aims to build a research station in the southern polar region of the Moon, as well as to create its own large-scale space station [Campbell, 2019].

Fifth, the creation and reconstruction of cosmodromes. The company Wenchang Launch Site held its first launch from a new generation pad. The launch sites of three "old" cosmodromes were also reconstructed [Guoli, 2016].

Sixth, the improvement of space telemetry. The Tianlian-1 Data Station system successfully fulfills its function of receiving data from satellites, such as altitude, charge of electrical sources, temperature, and position in space. From this, ground stations get an idea of the satellite's operational readiness and payload. In China, TT\&C stations of deep space coverage were built and put into operation during this time. Constantly the quality of space telemetry, tracking and command execution are being improved [Annual, 2008].

Seventh, the implementation of space programs for the use of earth observation satellites. The programs are widely used for the needs of public administration, business and civil sector to ensure the economic and social development of Chinese society. Communication and broadcasting satellites have improved communication services. In particular, television services, distance education and medicine. The emergency satellite communications system has provided reliable support in the fight against floods and droughts and other emergencies. The use of navigation and positioning satellites has simplified the operation of land and air transport and has made it possible to forecast the weather more accurately. Taken together, this will create a new business model for modern telecommunications technologies consisting of satellite programs and the Internet. This has provided a variety of Chinese individuals and legal entities with convenient and high-quality space-related services [Meng, 2018].

Eighth, the development of academic science. In the field of academic research, Chinese scientists use the latest space technologies, for example, the Shijiang-10 satellite was successfully launched to detect particles of dark matter. Experiments were also conducted using Chang'e lunar probes. The understanding of the mechanism of biological growth of plants under conditions of space microgravity and intensive radiation has been deepened [White Paper, 2016].

Ninth, solving space junk problems. Some progress has been made in monitoring and mitigating the effects of space debris being left in space. National norms and standards in this area have been deepened.

The leading role in the system of space activities rests on specialized research institutions. For example, the Beijing Institute of Space Law Institute was established in 2006. It is one of the first specialized institutions for teaching and exploring space law in China. Since its

\footnotetext{
${ }^{1}$ When the Chinese taikonaut Yang Liwei, having made 14 circles in the orbit, successfully returned to the Earth. Thus, China became the third country in the world to master manned space flights. The Shenzhou-9 and Shenzhou-10 spacecraft were launched, which were adapted to the Tiangong-1 space station. In 2016, space laboratory Tiangong-2, Shenzhou-11 were launched. Now more than 10 Chinese taikonauts have visited the space, including a woman.
} 
founding, with the support of academia at home and abroad, it has achieved considerable success [Annual, 2008].

So, in recent decades, through the successful implementation of space programs, China has become a leading space state, which is ranked at present as the first in the world in all ways of exploring and using outer space possible technologically. In other words, China has made significant strides in space exploration and exploitation. We conclude that the existing public economic relations in China's space industry are far ahead of national space law.

\section{Space plans of China}

According to the Chinese party and state leadership, space activities are one of the most complex high-tech industries that have a huge positive impact on other industries. Space activities have greatly enhanced human knowledge of space and have become an important driving force for social progress. Currently, more and more countries are making the development of space activities an important factor in their strategic choices. China is in the forefront in this list.

The leaders of the People's Republic of China (PRC) attach great importance to the development of the space industry. Chinese scientists emphasize that currently 29 countries have adopted national laws governing the space industry. However, the PRC is the only country among space nations that does not have a special space law. Accordingly, accelerating the creation of space legislation and new space technologies are the leading activities of the Government of China and a way to realize the dream of the Chinese people in the space field.

By 2049, China plans to become a rich and powerful nation, a leading space-power nation that has mastered artificial intelligence (AI) and developed extensively through innovative technologies. Chinese President Xi Jinping said that China's space program should play a decisive role in achieving these interconnected goals. With this purpose, China's Space Program aims to create long-term wealth for the Chinese nation. Today, China's space program funding is $\$ 350$ billion, and, as it is estimated, it would have reached $\$ 2.7$ trillion by 2040 . This should ensure the significant economic growth of the space industry and the profits of Chinese space companies. For example, Chinese scientists argue that using useful resources from just one platinum asteroid UW158, which flew 1.5 million miles from Earth in July 2015, could bring to its developers about $\$ 5$ trillion [Goswami, 2019].

In other words, the planning and implementation of space programs is a strategic factor in the development of China for the next decades and an integral aspect of the future viability of Chinese citizens.

Relying on space technology, the party and governmental institutions of the PRC carry out complex measures, both in the real use of outer space and in propaganda in this field. For the latter purpose, a White Paper on Space Activity was published in 2016 stating that China's space program was an integral part of the national goals of economic renewal and development.

On April 24, 2016, China officially established and celebrated Space Day for the first time, which was founded in honor of the launch of the first Chinese satellite on April 24, 1970. A striking example in this area is also the words spoken by Xie Tao on the board of the Tiangong-1 space station, who emphasized that the cosmic dream was part of the dreams of the Chinese people who desire to explore the vast cosmos, develop the space industry, and build China's future in the cosmic state [Goswami, 2019]. 
In 2020, a Chinese private company is about to send a reusable spacecraft for the first flight. Its largest version will be able to lift 20 people to a height of $130 \mathrm{~km}$ and provide them with four minutes of weightlessness. Such flight will cost the tourist about 200-250 thousand dollars. It is much cheaper than space companies of other countries charge for such a service. For example, the first space tourist paid Roskomos \$20 million. It is logical that just in this sphere of comic services more legal challenges occur but not financial ones. After all, it is necessary to regulate the legal status of space tourists and space taxi crew members; to state their subjective rights and legal obligations clearly; to determine the legal responsibility of each member of the space mission.

Authorities assure the world that China will have become the world's leading global econom by 2050. This forecast, in our view, is realistic based on the dynamics of China's GDP growth over the past ten years and the significant increase in quality of complex industrial products produced by Chinese business.

The Chinese economy and the Chinese people will need enormous natural resources. The Chinese authorities are aware that their number on the planet Earth is limited, so their thoughts were sent into outer space. After all, there is titanium, gold, silver, thorium, magnesium, platinum, silicon, water, aluminum and iron. So, according to Chinese scientists, the Moon can serve as a new and huge supplier of energy and resources to humans. China's Chang'e 4 robotic complex is currently operating on the Moon. In the future, China wants to build a permanent research station on the Moon, which will also become a territorial platform for mining on asteroids. All these issues require legal support. After all, the future extraction of natural resources by Chinese companies from space bodies, especially the Moon, is critically viewed by space states, especially the United States.

Another challenge that requires legal regulation through the adoption of Chinese national space law is the active development of private space companies. For example, a private Chinese company LinkSpace plans to launch a rocket by 2020 that is capable of vertical takeoff and vertical landing. Other space companies also operate in this market, and the fact that China's private space companies have already foreign clients brings China not only private investment in the space industry, but also convinces the market that such enterprises are an existing reality for this country [Demchenko, 2018]. In this direction, there is an ambitious plan of Chinese space scientists. In 2021, they want to launch a mission that will "saddles" a small near-earth asteroid in 2025 [Zyryanova, 2018].

Therefore, space plans are large in China, where governmental institutions raise the issue of developing space exploration and growth as a strategic goal of the Chinese nation. The global goal is to build a cosmic state in the medium and long term. Such a state should not only provide advanced satellite communications, navigation, analysis of natural and manmade situations on the Earth and manned astronautics, but also provide its industry with useful resources from space bodies (the Moon, asteroids).

\section{Current legal regulation of China's space industry}

Analyzing the current legal regulation of China's space industry, it is impossible to ignore some special aspects of the theory of law that distinguish it from the similar Western one. The differences between Chinese socialist theory of law and other legal theories are as follows.

First, the point of view of historical materialism is adhered, in which the right is a superstructure over economic relations of a certain level. The law may not exceed the level of development of socio-economic conditions. 
Second, it is the class nature of law, through which the ruling class corrects social relations. Third, the law must be developed simultaneously with the development of society. In general, Chinese scientists understand the law as social rules of conduct, which are formulated or recognized by the state, and reflect the will of the state, determine the rights and obligations of persons and are guaranteed against violation by the coercive force of the state [Chunying, 2015].

At the same time, the hierarchy of Chinese legislation is defined almost as in the western countries. At the top of the hierarchy of legal norms is the Constitution, followed by the laws of China And the third stage is occupied by the administrative and legal regulations of the State Council. The lowest level of Chinese law is the subordinate regulations of ministries and local authorities. A separate line deals with international treaties ratified by the National Assembly of China.

Given these factors, and the fact that China does not have a national space law, that country is a unique leading space state that has made significant progress in the exploration and use of outer space.

However, the lack of formal national civil space law, in our opinion, does not mean that there is no legal regulation in the field. It is clear that this can not by so. Without the regulation of important rules of social life with the help of legal norms it is impossible to achieve success in any field.

In our view, special rules for space-based activity in China have existed since the inception of the space industry. However, they are secret. Since the use and exploration of outer space in China was initially carried out by the military exclusively, despite the penetration into this area the civilians and even individuals, it continues to be carried out under a military umbrella.

We came to this conclusion by analogy, since China does not disclose its organizational and management documents, which are devoted to the military space, namely, by analogy with the Soviet space program. For example, in 1946, the Council of Ministers approved the state missile program, and its implementation was carried out by the Ministry of defense of the USSR. For its implementation within the framework of the armed forces, a military research Institute - the state Central training ground in the city of Kapustin-Yar of the Astrakhan region of Russia was formed. Almost all the employees of this training ground were military, and their activities were regulated not by civil legislation, but by the statutes of the armed forces and orders of the Ministry of defense of a normative nature. At the same time, the development of long-range missiles was carried out directly under the supervision of the Ministry of state security of the USSR, and funding was carried out at actual costs without limiting the size [USSR, 2011]. Indirectly, the analogy of this case is confirmed by the theses of some Chinese scientists who note that the main obstacle to the adoption of Chinese civil space law is the military [Li, 2012].

However, for fairness, it should be noted that the Chinese military industry also publishes some of its regulations, namely the State Council and the Central Military Commission of China issued a joint resolution of October 22, 1997, which approved the Regulation on Export Control of Military Goods. This provision also applies to the export of military space products. The state Council of China on August 22, 2002, adopted a resolution approving the rules of law on export control of guided missiles and the list of related items and technologies to be exported [Does, 2016]

This dominance of the closed military norms of space law leads to the fact that the Directorate of the International space Agency believes that now in China there are no legislative or administrative-legal norms, which in their essence are the norms of the national space law [Does, 2016]. 
What with we cannot agree in full, because there are two special low-level regulations in China. They regulate the issues of launching and registering space objects.

The Commission for Science, Technology and Industry for National Defence (COSTIND), together with the Ministry of Foreign Affairs, adopted a resolution on 8 February 2001, which outlines measures for the administration of space objects registration. According to this regulation, space objects launched for the purpose of exporting resources to space and to celestial bodies must be registered. The registration rules apply to all space objects launched from China and space objects jointly launched with other countries.

The second by-law of China's national space law is the provision of November 21, 2002, approved by COSTIND. It sets out temporary arrangements for managing the licensing of civilian space launch projects and the examination and licensing process for civilian space launch projects [Does, 2016].

In addition, there are quite sophisticated rules of space law in China that reduce space debris, which is positively emphasized by the International Comic Agency Directorate. These rules are approved by a by-law — the Space Administration of Science, Technology and Industry for National Defense, as a space debris action plan [Does, 2016].

In general, as the Chinese scientist Xiaodan $\mathrm{Wu}$ rightly pointed out, China's space regulation is governed by the general norms and principles of the international space law, international space treaties, and executive regulations [Wu, 2019]. We would also add that closed rules of epy military occupy a leading place in this regulation. Scientist explains this peculiarity of legal regulation of China in terms of historical, political, legal and administrative directions of the country's development.

Therefore, the regulation of the Chinese space industry is not based on a national special space law, but rather on the basis of low-level civil by-laws and closed-ended military regulations. Thus, it is unbaked that China's national space law is underdeveloped compared to the state's space capabilities. Thus, it is undisputed that China's national space law is underdeveloped compared to the state's space capabilities.

However, the need to regulate space relations at the national legislative level is understood by both the Communist Party leadership and the Chinese government. This is justified by the need to introduce the rule of law with Chinese specificity in all spheres of society and to fulfill the international commitments to improve governance and transparency in the international cooperation. The space law was included in the five-year legislative plan of China's National Assembly but it has not been adopted, since a major problem in the adoption of this law is that the leading role in the space activities of modern China is played by the military [ $\mathrm{Wu}, 2019]$. In our view, they do not want to lose their leading position in the space industry, have a large lobby in the National Assembly of China and therefore delay the adoption of this law.

Despite the fact that there is no national space law in China, doctrinal developments of Chinese scientists in the field of space law are carried out. Thus, the monograph "Special Study of the Theory and Practice of the Development of Chinese Space Law" [Study, 2019] is a comprehensive study of the problems of the space industry faced by Chinese society. In particular, the paper deals with the issues of legal regulation: satellite navigation systems; manned flight systems; the status of astronauts; space protection of intellectual property in space stations; rules of trade in space technologies and space products; protection of Chinese space products; rules of development of space tourism, international legal specifications of space tourism; rules of research and development of natural resources on the Moon. 
As it has been already mentioned, in addition to the national regulations, international treaties are used to regulate the space industry. In particular, China has signed a Memorandum of cooperation in the space field with Luxembourg, the state, that codified the law that gives space companies the right to extract minerals from space bodies (a similar law was adopted in the US) [Arcesati, 2019].

Thus, China is the only space power that does not have its own space law. Regulation of public relations in the field of exploration and use of space is carried out on the basis of the international norms-principles of space law, international treaties and by-laws of the executive bodies of the People's Republic of China. However, the governing bodies of China and scientists insist on the need to adopt a national space law, which is probably opposed by the military, who are lobbying their corporate interests, in our view.

\section{China's future space law. Basic outlines}

The creation of a complete system of national space law is based on the specificity of the socialist strategy of Chinese society, built on the principle of the rule of law.

The Nineteenth National Congress of the Communist party of China on October 18, 2017 put forward a strategic plan for the rule of law in the new era of socialism with Chinese characteristics [Xi, 2017].

The decisions of this congress emphasize that peaceful use of outer space is a consistent national policy of the People's Republic of China, respectively, there is an urgent requirement to refine and adopt a space law that should [Xi, 2017]:

1. Become the most important legal factor in the regulation and development of China's space activities.

2. Comply with the norms of the International Space Law, as well as the current national legislation, in particular: on national security, on state secrets, on the principles of civil law, on legal responsibility, as well as to be correlated with the norms of patent and civil procedure law.

3. Standardize and regulate all aspects of aerospace activities.

4. Introduce a system of public administration, licensing, registration of space objects and compensation for losses caused by comic.

5. Regulate the legal status of space infrastructure facilities.

6. Promote further industrialization and commercial development of space services.

7. Meet the needs of economic, scientific and technological development, national security and social progress of Chinese society.

8. Strive to increase China's overall national potential.

In addition, it is necessary to approve a mechanism for public administration, efficient allocation of resources, and funding for space projects in this law. Most importantly, it should spell out the rights, responsibilities and responsibilities of the parties involved in space activities. It should solve the problem of general planning, division of labor and resources, and cooperation. It should involve commercial resources and commercial companies in China's space industry.

However, the law should spell out the right of PRC to self-defence in accordance with the Charter of The United Nations. China's basic position on space security should be clarified. The category of "red line", for which other space powers should not pass, was introduced into 
the legal circulation. Also, a significant role in the law should be given to the protection of outer space from space debris [Wang, 2018].

If to analyze the provisions of the Nineteenth National Congress of the Communist Party of China on the basic contours of the newest national space law, we come to the conclusion that its scope will be the rules of law that should regulate space activities. These norms will include: the content of space activities; the limits of China's national jurisdiction in space; the ratio of international and national jurisdiction; the legal status of space entities, including public authorities; issues of registration of space activities and space objects; rules for launching rockets and space objects into outer space, their exploitation and their return to the Earth.

Therefore, the core of the social interests of Chinese society is space activity. The outer expression of space law will be the leading national rules of space law. This law will apply to the entire territory and to all public authorities, all Chinese citizens and any space and related companies incorporated in China.

\section{Conclusions}

The article reveals the past, present, and the authors vision of China's future space law. The leading conclusions of the article are the facts which state that without adopting a special space law:

firstly, the fundamental principles of the existence of modern China will be violated - the introduction of the rule of law with Chinese characteristics in all spheres of public life;

secondly, foreign investment in the Chinese space industry will be restrained;

thirdly, international partners will have doubts about the transparency of the activities of Chinese space companies.

In future works the legal instruments of the future Chinese space law will be analyzed.

\section{References}

Accelerate Space legislation, build a Space powerhouse. International Space, 2018. http:// www.taikongmedia.com/Item/Show.asp?m=1\&d=25542

Annual Chinese Space Law. World Knowledge, 2008. https:/www.sanmin.com.tw/Product/ Index/001200348

Arcesati, Rebecca. China's space program is about more than soft power. Mercator Institute for China Studies, 2019. https://www.merics.org/cn/node/8871

Campbell, Charlie. From Satellites to the Moon and Mars, China Is Quickly Becoming a Space Superpower. TIME, 2019. https://time.com/5623537/china-space/

Chunying, Xin. Several basic questions of legal theory. Chinese legal network, 2015. https:// www.iolaw.org.cn/shownews.asp?id=6198

Demchenko, Natalia. China came in first Place in the World in the number of Space Launches. RBK, 2018. https://www.rbc.ru/technology_and_ media/21/12/2018/5c1cab859a794752496ff07e

Does International Space Law Either Permit or prohibit the taking of Resources in outer Space and on celestial bodies, and how is this relevant for National Actors? What is the context, and what are the contours and limits of this permission or prohibition? International Institute of Space Law, Directorate of Studies (IISL), 2016. http://iislweb. org/docs/IISL_Space_Mining_Study.pdf 
Feng, Lixia. The Contemporary Significance of the Sinicization of Marxist Legal Theory. China Daily, 2018. http://china.chinadaily.com.cn/2018-11/14/content_37257783.htm

Goh, Deyana. China's upcoming missions according to its 5-Year Plan \& Space White Paper. SpaceTech Asia, 2017. http://www.spacetechasia.com/chinas-upcoming-missionsaccording-to-its-5-year-plan-space-white-paper/

Goswami, Namrata. China Has a Head Start in the New Space Race. The Diplomat, 2019. https://thediplomat.com/2019/05/china-has-a-head-start-in-the-new-space-race/

Li, Guoli. China Wenchang Space Launch Site was named and basically meets various requirements for satellite launch. Shanghai Oriental Newspaper Co., Ltd., 2016. https:// www.thepaper.cn/newsDetail_forward_1554751

Li, Juqian. China's Space Law and Regulation. China University of Political Science and Law, 2012. №.9. https://swfound.org/media/95017/li-china_space_law_regulation-nov2012. pdf

Meng, Wang. In space, more and more "Chinese stars". People's Daily Overseas Edition, 2018. http://www.xinhuanet.com/politics/2018-06/22/c_1123018850.htm

Qing, Shang. China's "Shenzhou” manned space history. $B B \bar{C}, 2013$. https://www.bbc.com/ zhongwen/trad/china/2013/06/130611_china_shenzhou_timeline

Study on the Theory and Practice of the Development of Chinese Space Law. LAW-LIB, 2019. http://www.law-lib.com/shopping/shopview_p.asp?id=80414

USSR Space Program. Encyclopedia of World History (EWH), 2011. https://w.histrf.ru/ articles/article/show/kosmichieskaia_programma_sssr

Wang, Yulian. Speeding up space legislation Building a space powerhouse (Accelerating Space Legislation Building Space Power), 2018. http://www.taikongmedia.com/ UploadFiles/2018-06/23/15300597478733519.pdf

White Paper on China's Space Activities in 2016. China Daily, 2016. http://english.gov.cn/ archive/white_paper/2016/12/28/content_281475527159496.htm

White Paper: China's Space Activities in 2016. China.org.cn, 2017. http://www.china.org.cn/ chinese/2017-01/10/content_40073952.htm

Wu, Xiaodan. China's Space Law: Rushing to the Finish Line of its Marathon. Elsevier. Volume 46, November 2018, Pages 38-45. https://doi.org/10.1016/j.spacepol.2018.03.004

$\mathrm{Xi}$, Jinping. Opening up a new situation of the cause of Socialism with Chinese characteristics in the new Era. GOV.CN, 2017. http:/www.gov.cn/zhuanti/19thcpc/index.htm

$\mathrm{Xi}$, Jinping. Strengthening the party's leadership over the rule of law in a comprehensive manner, 2019. http://www.xinhuanet.com/politics/2019-02/15/c_1124120391.htm

Zyryanova, Anastasia. Catch up and overtake: how big is China's space ambitions. $B B C, 2018$. https://www.bbc.com/russian/features-43622041 